\title{
PENGARUH TEKNIK SELF-INSTRUCTION DALAM PENDEKATAN COGNITIVE BEHAVIOR THERAPY UNTUK MENINGKATKAN HARGA DIRI KORBAN PERUNDUNGAN
}

\author{
Rahmah Salsabila ${ }^{1}$ \\ Hilma Fitriyani ${ }^{2}$
}

\begin{abstract}
Abstrak
Penelitian ini bertujuan untuk mengetahui pengaruh teknik self-instruction dalam pendekatan CBT untuk meningkatkan harga diri korban perundungan. Penelitian ini menggunakan metode penelitian subjek tunggal dengan desain A-B. Subjek dalam penelitian ini adalah seorang siswa laki-laki kelas VII SMP yang memiliki harga diri rendah berdasarkan hasil pengukuran harga diri instrumen coopersmith self-esteem inventory. Data yang diperoleh selama penelitian kemudian dianalisis dengan cara analisis dalam kondisi pada kondisi baseline (A) dan kondisi intervensi (B) serta dilakukan analisis antar kondisi baseline (A) dengan kondisi intervensi (B). Skor pada kondisi baseline cenderung stabil dan skor pada kondisi intervensi cenderung meningkat. Rata-rata skor harga diri sebelum dilakukan intervensi adalah 66 (berada pada kategori rendah) kemudian meningkat menjadi 93 (berada pada kategori sedang) setelah diberikan intervensi. Hasil persentase overlap pada penelitian ini memperlihatkan bahwa teknik self-instruction berpengaruh pada meningkatnya harga diri konseli.

Kata Kunci: teknik self-instruction, korban perundungan, harga diri, cognitive behavior therapy.
\end{abstract}

\begin{abstract}
The study aims to determine the effect of self-instruction techniques CBT in bullyvictims to improve students self-esteem. This research using a single subject research method with A-B design. The subject in this study was a seventh grade male student in junior high school with a low level of self-esteem based on coopersmith self-esteem inventory's instrument. The data obtained were analyzed in analysis under conditions in baseline condition $(A)$ and intervention condition (B) and an analysis between baseline condition $(A)$ with intervention condition (B). Cores at baseline conditions tend to be stable and scores at intervention conditions tend to increase. The conselee's average self-esteem before intervention was 66 (in low category) then increased into 93 (in medium category) after intervention. The overlap percentage results in this study show that the self-instruction technique affects the increasing self-esteem of the counselee.

Keywords: self-instruction techniques, bully victim, self-esteem, cognitive behavior therapy.
\end{abstract}

\footnotetext{
${ }^{1}$ Universitas Negeri Jakarta, rahmahsalsabila31.rs@ gmail.com

${ }^{2}$ Universitas Negeri Jakarta, hilma@unj.ac.id
} 
Perundungan (bullying) adalah masalah yang masih sering terjadi pada remaja Indonesia. Komisi Perlindungan Anak Indonesia (KPAI) bidang pendidikan mencatat per bulan Mei 2018 terdapat 77 kasus mengenai kekerasan dan perundungan remaja di Indonesia (Novianto, 2018). Perundungan (bullying) dapat dipahami sebagai perilaku agresif yang disengaja, dilakukan oleh seseorang atau sekelompok orang dari waktu ke waktu secara berulang-ulang terhadap seseorang korban yang tidak berdaya. Bisa juga dikatakan sebagai penyalahgunaan kekuatan atau kekuasaan secara sistematik (Kathryn, 2012).

Penelitian korelasi terkait hubungan perundungan dengan harga diri remaja menunjukkan hasil bahwa apabila tingkat perundungan yang dialami semakin tinggi maka tingkat harga diri akan semakin rendah, dan apabila pengalaman mendapatkan perundungan semakin rendah maka cenderung memiliki harga diri yang tinggi (Liow et al., 2009; Saniya, 2019). Kemudian Santrock (2007) menjelaskan bahwa penurunan harga diri pada remaja berlangsung selama masa transisi dari awal atau pertengahan hingga akhir sekolah menengah atas, dan dari sekolah menengah atas hingga kampus. Remaja pada masa transisi awal adalah remaja yang berusia sekitar 13-15 tahun dan berada pada tingkatan remaja awal (WHO, 2018). Remaja awal cenderung banyak menghabiskan waktu dengan teman sebayanya dibandingkan dengan keluarganya (Santrock, 2007). Mereka banyak melakukan penyesuaian sosial dan mencari afiliasi sebaya (WHO, 2018). Pengalaman perundungan yang berdampak pada harga diri remaja yang rendah (Liow et al., 2009; Saniya, 2019), membuat mereka cenderung mengalami kecemasan sosial (Tirsae, 2016) sehingga kesulitan dalam melakukan penyesuaian sosial (Khoirunafik, 2018).

Salah satu cara yang dapat dilakukan untuk membantu remaja tersebut adalah mendapatkan layanan bantuan dari konselor. Adapun layanan bantuan spesifik yang dapat diberikan oleh konselor salah satunya yaitu dengan menerapkan konseling individu. Pemilihan layanan konseling individu disesuaikan dengan tujuan pelaksanaan konseling individu yakni terjadinya perubahan perilaku konseli yang berakhir pada teratasinya masalah yang dialami oleh konseli (Azam, 2016). Pelaksanaan konseling individu ini, membantu konseli secara perseorangan dalam mengatasi permasalahan yang dimilikinya dengan bantuan dari konselor. Mengacu pada kesesuaian permasalahan yang dialami oleh individu. Adapun salah satu teknik yang dapat dipilih untuk membantu individu meningkatkan harga diri yakni teknik self-instruction (Corey, 2009).

Teknik self-instruction adalah salah satu teknik cognitive behavior modification yang juga merupakan bentuk dari pendekatan konseling cognitive behavioral therapy (CBT). Konseli akan belajar untuk mengubah cara dia berfikir dengan fokus pada mengubah verbalisasi konseli. Sehingga akan berdampak pada pikiran, perasaan, dan pada perilaku konseli. Penelitian yang dilakukan oleh Rostiana, Wibowo, dan Purwanto (2018) membuktikan bahwa pendekatan CBT dengan teknik self-instructions efektif meningkatkan harga diri konseli korban perundungan usia 13-14 tahun. Penelitian lain yang juga memberi kesimpulan bahwa selfinstruction efektif untuk meningkatkan self-esteem adalah penelitian yang telah 
dilakukan oleh Putu dan Lestari (2014) dengan subjek penelitian beberapa siswa kelas XI SMA yang teridentifikasi memiliki harga diri yang rendah, dan penelitian oleh Larasati (2012) dengan subjek penelitian seorang siswi SMP kelas VII berusia 13 tahun

\section{Harga Diri}

Coopersmith (1967) menjelaskan bahwa harga diri adalah evaluasi yang dibuat dan dipertahankan oleh individu terhadap dirinya sendiri, yang diekspresikan dalam sikap menerima atau menolak dirinya sendiri, dan mengindikasikan tingkat kepercayaan dirinya untuk menjadi kompeten, berarti, sukses, dan layak.

Branden (2013) mendifinisikan harga diri sebagai pengalaman yang individu alami untuk menjadi kompeten dalam mengatasi tantangan dasar kehidupan untuk mencapai kebahagiaan. Kemudian harga diri juga membentuk keyakinan diri individu mengenai kemampuan berpikirnya, keyakinan individu untuk belajar, membuat pilihan, membuat keputusan, dan merespon secara efektif pada perubahan. Harga diri didasarkan pada kenyataan yang dibangun dari waktu ke waktu melalui operasi pikiran yang tepat.

Coopersmith

mengungkapkan bahwa terdapat empat aspek utama dalam harga diri, aspekaspek tersebut adalah sebagai berikut. (1) Harga diri personal: menunjukan kemampuan individu untuk melakukan penilaian terhadap kemampuan dirinya secara umum. (2) Harga diri sosial: menunjukan kemampuan individu dalam berhubungan dengan orang lain. Harga diri sosial memperlihatkan perhatian, kepedulian, dan afeksi yang diterima individu dari orang lain. Hal itu merupakan penghargaan dari orang lain dan tanda penerimaan dan popularitasnya. Keadaan ditandai dengan kehangatan, keikutsertaan, perhatian, dan kesukaan orang lain terhadapnya. (3) Harga diri keluarga: menunjukan hubungan individu dengan keluarganya. Harga diri keluarga memperlihatkan seberapa besar kedekatan anak dengan orang tua, dukungan orang tua terhadap anak, dan penerimaan orang tua terhadap anak. (4) Harga diri akademis: menunjukan kepercayaan diri individu, kemampuan belajar, dan kepatuhan individu dalam setiap kegiatan sekolah. Harga diri akademis juga memperlihatkan usaha yang tinggi dari individu untuk mendapatkan prestasi yang baik, sesuai dengan usia perkembangannya. Hal ini ditandai dengan keberhasilan individu dalam mengerjakan berbagai macam tugasnya dengan baik.

\section{Perundungan}

Perundungan dapat dipahami sebagai perilaku agresif yang disengaja, dilakukan oleh seseorang atau sekelompok orang dari waktu ke waktu secara berulang-ulang terhadap seseorang korban yang tidak berdaya. Bisa juga dikatakan sebagai penyalahgunaan kekuatan atau kekuasaan secara sistematik (Kathryn, 2012).

Penelitian kolerasi terkait hubungan perundungan dengan harga diri remaja menunjukan hasil bahwa apabila tingkat perundungan yang dialami semakin tinggi maka tingkat harga diri akan semakin rendah, dan apabila pengalaman mendapatkan perundungan semakin rendah maka cenderung memiliki harga diri yang tinggi (Liow et al., 2009; Saniya, 2019). 


\section{Teknik Self Instruction}

Teknik self-instruction adalah salah satu teknik cognitive behavior modification yang juga merupakan bentuk dari pendekatan konseling CBT. Teknik Self-instruction atau teknik instruksi dikembangkan oleh Donald Meichenbaum pada tahun 1977. Teknik ini bertujuan untuk membantu konseli lebih sadar akan self talk atau percakapan internal dalam dirinya. Proses dalam teknik ini adalah dengan mengajari konseli untuk membuat self-statement (pernyataan diri) dan melatih konseli untuk mengubah instruksi yang diberikan pada diri mereka sendiri. Proses dalam teknik ini dalam CBT juga dikenal dengan sebutan rekonstruksi kognitif. Konseli akan belajar untuk mengubah cara dia berfikir dengan fokus pada mengubah verbalisasi konseli. Sehingga akan berdampak pada pikiran, perasaan, dan pada perilaku konseli (Corey, 2009).

Meinchenbeum (Corey, 2009), menggambarkan proses tahapan teknik self-instruction ke dalam 3 tahapan berikut. (1) Observasi diri: di awal intervensi, konseli diminta untuk mendengarkan dialog internal dalam dirinya dan mengenali karakteristik pernyataan negatif yang ada. Proses ini melibatkan kegiatan meningkatkan sensitivitas terhadap pikiran, perasaan, perbuatan, reaksi fisiologis dan pola reaksi terhadap orang lain. (2) Memulai dialog internal baru: setelah konseli belajar untuk mengenali tingkah laku maladaptifnya, mereka mulai mencari kesempatan untuk mengembangkan alternatif tingkah laku adaptif dengan cara merubah dialog internal dalam diri mereka. Dialog internal yang baru diharapkan dapat menghasilkan tingkah laku baru, yang sebaliknya akan memberikan dampak terhadap struktur kognisi konseli. (3) Belajar keterampilan baru: konseli kemudian belajar teknik mengatasi masalah yang secara praktis dapat diterapkan dalam kehidupan sehari-hari. Pada saat yang sama, konseli diharapkan untuk tetap memusatkan perhatian kepada tugas membuat pernyataan baru dan mengamati perbedaan hasilnya.

Cormier (2009) menjelaskan bahwa terdapat lima tahapan dalam selfisntruction: (1) konselor berfungsi sebagai model (atau model simbolik) dan pertama melakukan tugas sambil berbicara dengan lantang untuk dirinya sendiri. (2) konseli melakukan tugas yang sama (seperti yang dimodelkan oleh konselor) sementara konselor menginstruksikan konseli untuk mengulang seperti yang dilakukan konselor dengan suara yang lantang dan jelas. (3) konseli diinstruksikan untuk melakukan tugas yang sama lagi saat menginstruksikan dirinya sendiri. (4) konseli melakukan intruksi terhadap dirinya sendiri dengan suara lirih (5). konseli melakukan tugas sambil menginstruksikan dirinya sendiri di dalam hati.

\section{METODE PENELITIAN}

Metode penelitian ini adalah eksperimen, dengan desain single subject research atau penelitian subjek tunggal. penelitian subjek tunggal dengan karakteristik penelitian yakni intensif, sistematis atau dilakukan dengan penjadwalan yang teratur, dapat menghasilkan informasi keunikan respon konseli sebagai subjek penelitian dan intervensi yang diberikan oleh konselor sebagai peneliti (Whiston, 2009)

Subjek yang terlibat dalam penelitian ini dipilih menggunakan teknik purposive sampling yaitu teknik 
sampling yang memiliki tujuan atau pertimbangan tertentu (Sugiono, 2013). Kriteria subjek penelitian yang dipilih yakni remaja usia 13-15 tahun korban perundungan dan memiliki tingkat harga diri rendah. Penelitian ini dilakukan di dan waktu penelitian dilakukan pada bulan Juli 2018 hingga Februari 2020.

Kemudian instrumen penelitian ini menggunakan instrumen Copersmith Self-Esteem Inventory (CSI) yang telah diadaptasi oleh Prabowo (2014). Lalu dilakukan uji validitas dan reliabilitas kembali dengan hasil skor reliabilitas sebesar 0.894 .

\section{HASIL PENELITIAN}

Penelitian ini memiliki tujuan untuk untuk mengetahui pengaruh teknik selfinstruction dalam pendekatan cognitive behavior therapy terhadap peningkatan harga diri korban perundungan (bullying). Penelitian ini dilakukan melalui layanan konseling individu yang dilakukan selama 11 sesi konseling, 4 sesi pertama adalah wawancara awal dan konseling tahap eksplorasi dan konseptualisasi masalah, 7 sesi selanjutnya adalah konseling dengan tahapan proses implementasi selfinstruction yang yang mencakup proses restrukturisasi kognitif, latihan verbalisasi pernyataan positif dengan suara lantang, berbisik, dan dalam hati, penerapan perilaku baru dan coping adaptif, kemudian evaluasi.

Hasil dari analisis data adalah diagram kecenderungan arah analisis dalam kondisi memperlihatkan bahwa terdapat sedikit penurunan skor harga diri setelah sebelumnya meningkat pada sesi keempat intervensi. Penurunan tersebut sangat berkaitan dengan kurangnya dukungan sosial yang konseli dapatkan ketika konseli melakukan penerapan perubahan perilaku.
Kemudian hasil level perubahan analisis dalam kondisi menunjukan bahwa pada kondisi baseline cenderung stabil dan kondisi intervensi cenderung terdapat peningkatan harga diri. Hasil analisis level perubahan analisis antar kondisi adalah peningkatan pada aspek harga diri personal, sosial, dan akademis. Selain itu juga tampak stabil pada aspek keluarga. Lalu hasil persentase overlap pada penelitian ini memperlihatkan bahwa teknik self-instruction berpengaruh pada meningkatnya harga diri konseli.

Konseli mengalami perundungan dari teman-temannya dalam bentuk perundungan verbal baik secara langsung atau lewat media sosial. Menurut Coloroso (2007) bentuk perundungan verbal diantaranya adalah mengintimidasi, menjuluki, menghina, menyebar rumor, memfitnah, merendahkan, mencela, memaki, dan mengancam, serta termasuk didalamnya cyber bullying. Berdasarkan penjelasan Coloroso (2007) hal-hal yang dialami oleh konseli berupa menjuluki, menyebar rumor, merendahkan, dan cyber bullying.

Berdasarkan hasil tes harga diri dengan instrumen harga diri Coopersmith (1967) menjelaskan bahwa konseli memiliki harga diri yang rendah secara keseluruhan dan mendapatkan kategori rendah pada aspek harga diri personal dan sosial. Kategori harga diri rendah menjelaskan bahwa konseli memiliki sikap diri yang negatif. Konseli merasa tidak lebih penting atau disukai dari pada orang lain, dia tidak punya alasan yang membuat orang lain menyukainya, konseli melakukan sesuatu karena berpikir bahwa hal itu harus dilakukan bukan karena dia ingin melakukannya dan dia tidak yakin dengan kemampuanya. Konseli juga berpikir ide atau pekerjaan orang lain 
lebih baik daripada miliknya, dia berpikir orang lain tidak perhatian dengannya dan dia tidak menyalahkan mereka atas hal itu. Konseli tidak menyukai hal-hal yang baru atau tidak biasa, dia lebih memilih untuk berada dalam situasi yang menurutnya aman.

Konseli tidak berharap banyak atas dirinya untuk sekarang atau dimasa depan, dia merasa sekalipun dia berusaha lebih keras hasilnya akan tetap menyedihkan, sehingga dia memilih untuk menyerah melakukan sesuatu yang penting atau bernilai. Kemudian rendahnya harga diri konseli pada aspek harga diri personal dan harga diri sosial menunjukan bahwa konseli memiliki sikap dan pandangan negatif atas kemampuannya dan merasa tidak menjadi bagian dari kehidupan lingkungan sosialnya, dia merasa tidak diterima dan tidak diakui. Meski demikian, sekarang ini konseli memiliki keinginan untuk tidak mendapatkan perundungan lagi, dapat mengontrol emosi, dan dapat meningkatkan kemampuannya dalam bersosialisasi. Kemudian konseli juga bersedia mendapatkan konseling.

Banyak ide-ide pikiran dan keyakinan-keyakinan konseli dalam menjalani kehidupan sehari-hari dikembangkan dari pengalamannya mendapat bullying dari teman. Penglamannya mendapat perundungan adalah hal utama yang mempengaruhi rendahnya harga diri konseli. Penelitian yang dilakukan oleh Saniya (2019). pengalaman perundungan yang dialami konseli cenderung menjadikan konseli memiliki harga diri yang rendah.

konseli memiliki pikiran otomatis "saya harus benar dalam melakukan sesuatu, tidak boleh salah atau gagal" jika membuat kesalahan maka ia akan semakin diejek dan direndahkan, ide ini muncul karena konseli sering kali diejek dan diremehkan kemampuannya, sehingga ia merasa tidak boleh melakukan kesalahan yang dia lakukan harus berhasil dan harus benar, membuat konseli kesulitan dalam mengambil keputusan, ragu dalam menjalankan tantangan, merasa cemas, merasa tertekan dan sangat takut melakukan kesalahan, serta takut gagal dalam menjalin hubungan pertemanan. Pikiran otomatis tersebut juga mengembangkan dialog-dialog internal negative seperti (1) "lebih baik tidak memulai pertemanan dari pada nanti ditinggalkan", sehingga membuat konseli mengalami kesulitan dalam memulai pertemanan karena ia merasa tidak mau tahu mengenai temantemannya lagi, sering merasa sedih dan merasa sendiri. (2) "lebih baik tidak perlu ambil tantangan dari pada nanti salah" sehingga membuat konseli takut salah dan berusaha menhindari tantangan yang sebenernya dapat dia lewati, juga membuat konseli sering merasa tidak dapat diandalkan.

(3)"teman-teman tidak akan mendengarkan, lebih baik diam dari pada nanti salah lagi" konseli selalu diam saja saat diejek meskipun perkataan yang temannya ejek tidaklah benar, juga tidak berusaha menjelaskan kepada temanteman lain yang hanya memperhatikan, konseli hanya merasa tidak berdaya, sedih, sampai pernah sangat marah dan tanpa mengatakan apapun langsung melempar bangku. (4) "lebih baik tidak mau kerja kelompok dari pada nanti salah", sehingga konseli selalu kebingungan saat kerja kelompok, tidak berusaha mencari kelompok, takut salah dalam melaksanakan tugas kelompok. (5) "saya harus benar dalam menjawab soal atau menjawab pertanyaan", 
sehingga membuat konseli kesulitan dalam menjawab soal ujian, dan tidak berani mengangkat tangan dan menjawab pertanyaan guru.

Kesimpulannya adalah bahwa konseli mengembangkan pemikiran keliru seperti "Should" and "must" statements, (juga disebut imperatives) yaitu, individu memiliki gagasan yang pasti dan pasti tentang bagaimana dirinya atau orang lain harus berperilaku, dan individu tersebut melebih-lebihkan betapa buruknya harapan-harapan ini tidak terpenuhi (Beck, 2011) Konsekuensi dari pikiran keliru tersebut dalam diri konseli menunjukan ciri-ciri harga diri yang rendah, seperti cenderung melakukan perilaku yang menghindar, memiliki keyakinan bahwa lebih baik untuk tidak mencoba atau sengaja tidak berusaha cukup keras dari pada mencoba yang terbaik dan gagal (Collins-Donnelly, 2014), kesulitan dalam membentuk keterikatan yang dekat, kecemasan dan kebingungan sehingga kesalahpahaman dapat terjadi dengan mudah dan terjadi di mana-mana, secepatnya mereka menolak orang lain sebelum mereka ditolak (Plummer, 2005), tidak punya alasan yang membuat orang lain menyukainya, tidak yakin dengan kemampuanya, lebih memilih untuk berada dalam situasi yang menurutnya aman, memilih untuk menyerah melakukan sesuatu yang penting atau bernilai (Coopersmith, 1967). Ciri- ciri harga diri rendah tersebut cenderung dimiliki oleh korban perundungan (Wiyani, Ardy, 2017).

Berdasarkan penelitian yang dilakukan dapat dikatakan bahwa teknik self-instruction merupakan teknik pendekatan cognitive behavior therapy yang dapat digunakan untuk meningkatkan harga diri korban perundungan pada siswa SMP. Pada aspek harga diri personal terjadi peningkatan skor dari rata-rata skor 27 (kondisi baseline) dengan kategori rendah, menjadi 44, 57 (kondisi intervensi) dengan kategori sedang. Peningkatan skor ini ditandai dengan terdapat banyak pandangan-pandangan positif dalam diri, pemahaman diri yang sudah lebih baik, dan penghargaan kepada diri sendiri. Konseli sudah lebih tau bagaimana cara dirinya berkembang, hal apa yang perlu dia lakukan, dan masa depan bagaimana yang akan dia capai. Meskipun demikian, konseli masih sering ragu dalam mengungkapkan apa yang dipikirkannya. Kategori sedang pada skor rata-rata harga diri konseli menunjukan bahwa konseli masih harus memperkuat instruksi positif untuk meningkatkan keyakinannya.

Pada aspek sosial terlihat peningkatan skor rata-rata dari 8 (kondisi baseline) dengan kategori rendah, menjadi 11,86 (kondisi intervensi) dengan kategori sedang. Peningkatan skor ini ditandai dengan keberanian konseli membangun pertemanan dengan beberapa teman baik, tidak banyak menyendiri, dan konseli juga mengetahui potensi dirinya didalam pertemanan. Terdapat satu indikator dalam aspek ini yang yang mendapatkan skor rendah, yaitu indikator yang menyatakan bahwa masih sering dari beberapa teman konseli yang menganggunya seperti mengejek dan merendahkannya. Hal itu menjelaskan bahwa konseli masih belum mendapatkan dukungan sosial dengan baik dari para teman-teman sebayanya. Dukungan sosial dari teman sebaya ini sangat berperan dalam peningkatan harga diri (Simanjuntak \& Indrawati, 2019). Kategori sedang dalam aspek sosial menunjukan bahwa dukungan sosial yang kurang dari teman sebayanya 
masih membuatnya kesulitan untuk membangun interaksi sosial yang menyenangkan.

Pada aspek keluarga terjadi sedikit peningkatan dari rata-rata skor 20,25 (kondisi baseline) kategori sedang, menjadi 21,71 (kondisi intervensi) kategori tinggi. Peningkatan pada aspek ini ditandai dengan konseli tidak lagi mudah bersedih ketika dirumah, rasa sedihnya ini muncul karena sering diejek disekolah atau di media sosial temanteman seangkatannya. Kondisi keluarga konseli sejak awal sudah sangat mendukung konseli untuk meningkatkan harga dirinya. Orang tua konseli selalu berusaha peduli dengan perasaan konseli dan berusaha mengerti serta memahami kondisi konseli. Orang tua konseli juga sering menghubungi guru BK untuk berdiskusi tentang perkembangan konseli, beberapa kali juga menghubungi konselor untuk meminta saran terkait hal yang pihak keluarga dapat lakukan untuk mendukung proses peningkatan harga diri konseli. Bentuk dukungan sosial dari keluarga yang demikian sangat berpengaruh dalam peningkatan harga diri konseli (Sancahya \& Susilawati, 2014).

Pada aspek akademik terjadi peningkatan skor rata-rata dari 10,75 (kondisi baseline) kategori rendah, menjadi 14,86 (kondisi intervensi) kategori sedang. Peningkatan pada aspek ini ditandai dengan perubahan yang terjadi pada perilaku konseli dikelas seperti mulai beraninya konseli dalam menjawab, bertanya, atau berpendapat saat jam mata pelajaran. Akan tetapi terdapat skor rendah pada indikator yang menyatakan bahwa konseli sering merasa sedih disekolah dan merasa tidak cukup dihargai oleh teman-teman di kelas. Konseli tampak sangat berjuang untuk berani melakukan perubahan perilaku positif dikelas dalam aspek akademik, namun hal tersebut kurang didukung oleh kondisi beberapa temanteman konseli yang masih sering mengejek konseli terutama bila konseli mencoba melakukan sesuatu namun keliru, seperti menjawab pertanyaan guru tapi salah maka ejekan dari beberapa teman-teman akan langsung didapatkannya. Hal tersebutlah yang membuat konseli merasa sering bersedih berada di sekolah. Meski demikian, rasa sedihnya tidak membuat konseli menyerah untuk terus melakukan perubahan perilaku positif. Kategori sedang dalam aspek ini menunjukan bahwa konseli masih dalam keadaan berjuang untuk meningkatkan kemampuannya di sekolah dengan terus melakukan perubahan perilaku dan coping adaptif meskipun respon temanteman sering tidak menyenangkan.

Pada sesi konseling 1-3 fokus pada eksplorasi, konseptualisasi masalah dan pengumpulan data baseline. Sehingga belum terlihat perubahan signifikan dan skor tingkat harga diri cenderung stabil dengan kategori rendah. Peningkatan harga diri konseli mulai terlihat pada sesi konseling 4 (skor harga diri 77) sampai dengan sesi konseling ke-7 (skor harga diri 103). Fokus proses konseling saat itu adalah rekonstruksi kognitif dan latihan instruksi diri dengan verbalisasi pernyataan positif, bisa dikatakan dua proses itulah yang sangat berpengaruh dalam meningkatkan harga diri konseli.

Rekonstuksi kognitif dilakukan dalam dua sesi bertujuan untuk mengubah pikiran otomatis yang keliru dan dialog internal negatif sehingga menghasilkan rumusan pikiran otomatis dan dialog internal yang lebih positif. Tahapan yang dilakukan dalam fase ini adalah sebagai berikut. (1) Menyampaikan kembali pikiran-pikiran 
otomatis yang dimiliki konseli dan dialog internal yang menyertainya serta dampaknya secara emosi dan perilaku dalam keseharian konseli. (2) Bersama konseli menganalisis peristiwa yang mendukung pikiran otomatis konseli dan menganalisis peristiwa yang tidak mendukung pikiran otomatis konseli. (3) Membantu konseli mengaitkan bagaimana pikiran otomatis dan dialog internal negatif mempengaruhi dampak merugikan yang konseli rasakan. (4) Membantu konseli menyadari bahwa pikiran otomatis yang konseli yakini adalah keliru, dikaitkan dengan pengalaman konseli yang tidak mendukung pikiran otomatis konseli. (5) Membantu konseli menyadari bahwa pikiran otomatis dan dialog negatif konseli perlu dirubah. (6) Membantu konseli merumuskan dialog internal baru yang lebih menguntungkan.

Dalam proses konseling rekonstruksi kognitif, konselor menggunakan tabel rekam kejadian dan perubahan pikiran sebagai media untuk memudahkan konseli melihat dengan jelas bagaimana cara berpikirnya selama ini keliru dan berkembang menjadi dialog internal negatif sehingga menguatkan konseli untuk melakukan perubahan pada pikiran otomatis dan dialog internal. Tabel rekam kejadian dan perubahan pikiran disusun dan dikembangkan dengan tujuan untuk memudahkan proses perubahan pikiran dan keyakinan (Cully \& Teten, 2008). Hasil dari proses ini adalah rumusan pikiran otomatis dan dialog internal baru. Keberhasilan proses rekonstruksi kognitif ditandai dengan perubahan cara berpikir konseli, cara konseli memandang sesuatu, dan cara konseli mengembangkan dialog internalnya. Pada sesi ini konseli juga terlihat lebih memahami dirinya sendiridan pandangan konseli mengenai banyak hal jauh lebih optimis.

Kemudian pada proses latihan selfinstruction dengan verbalisasi pernyataan positif juga dilakukan selama 2 sesi dan bertujuan untuk meninstruksikan secara berulang dialog internal yang telah dirumuskan tersebut untuk dirinya sendiri. Tahapan proses ini adalah sebagai berikut. (1) konselor berfungsi sebagai model (atau model simbolik) dan pertama melakukan tugas sambil berbicara dengan lantang untuk dirinya sendiri. (2) konseli melakukan tugas yang sama (seperti yang dimodelkan oleh konselor) sementara konselor menginstruksikan konseli untuk mengulang seperti yang dilakukan konselor dengan suara yang lantang dan jelas. (3) konseli diinstruksikan untuk melakukan tugas yang sama lagi saat menginstruksikan dirinya sendiri. (4) konseli melakukan intruksi terhadap dirinya sendiri dengan suara lirih. (5) konseli melakukan tugas sambil menginstruksikan kepada dirinya sendiri didalam hati. Kemudian konseli diwajibkan untuk mengulang-ulang latihan instruksi diri setiap hari.

keberhasilan proses ini ditandai dengan meningkatnya kemampuan konseli dalam mengelola emosinya ketika menghadapi ejekan teman-teman baik ejekan secara langsung maupun tidak langsung. Juga ditandai dengan lebih mudah bagi konseli untuk mengambil keputusan dan menentukan pilihan, konseli juga terlihat lebih mudah mengungkapkan pendapat, konseli juga tepat waktu dalam mengerjakan soal matematika karena konseli mengurangi kekhawatiran takut salahnya sehingga waktunya tidak habis untuk menghitung berkali-kali dan menghapus-hapus jawaban karena tidak yakin. 
Skor harga diri konseli mengalami sedikit penurunan ketika sesi konseling ke-8 menjadi 97, pada sesi ke-8 terjadi proses penerapan perilaku baru dan coping adaptif. Penurunan skor ini tampaknya dikarenakan konseli merasa bahwa ia masih sering bersedih karena ejekan teman-teman yang terus dia dengar, terlebih jika dia melakukan hal yang keliru, beruntungnya coping adaptif, rekonstruksi kognitif, dan instruksi diri membantunya tidak menyerah, mgembalikan sikap optimisnya dan terus berusaha melakukan perubahan perilaku serta mengelola emosi kesalnya. Lalu setelahnya skor harga diri cenderung stabil meningkat pada kategori medium sampai terminasi.

Hasil penelitian bahwa teknik selfinstruction dapat digunakan untuk meningkatkan harga diri korban perundungan mendapatkan penguatan dari penelitian sebelumnya yang telah dilakukan oleh Rostiana, Wibowo, oleh Purwanto (2018) bertujuan meningkatkan harga diri korban perundungan dengan teknik selfinstruction dan teknik thought stopping. Terdapat 21 siswa usia 13-14 yang menjadi objek penelitian, mereka dibagi menjadi 3 kelompok, kelompok pertama mendapatkan treatment dengan teknik self-instruction, kelompok kedua mendapatkan treatment dengan teknik thought stopping, dan kelompok ketiga mendapatkan teknik self-instruction dan thought stopping. Hasil dari penelitian tersebut menjelaskan bahwa secara keseluruhan menggabungkan teknik selfinstruction dan teknik thought stopping lebih efektif meningkatkan harga diri. Kemudian hasil lainnya yang diperoleh adalah teknik self-instruction lebih efektif meningkatkan harga diri korban perundungan dibandingkan dengan teknik thought stopping.

Secara keseluruhan tingkat harga diri konseli berada pada kategori sedang. Menurut Coopersmith (1967) karakteristik individu dengan harga diri sedang hampir sama dengan karakteristik individu dengan harga diri tinggi, terutama dalam kualitas, sikap, dan perilaku. Namun dalam keadaan tetentu individu memiliki keyakinankeyakinan seperti karakteristik individu dengan harga diri rendah. Maka dari itu meskipun terjadi peningkatan harga diri, konseli masih terus harus mendapatkan pendampingan untuk terus bersamanya berproses meningkatkan harga diri. Sehingga peneliti memutuskan bekerjasama dengan guru bimbingan konseling (BK) dan orang tua konseli untuk terus memberi dukungan kepada konseli dan mendampingi proses perkembangannya

\section{KESIMPULAN}

Berdasarkan penelitian dengan subjek tunggal yang telah dilakukan pada siswa korban perundungan dengan menerapkan teknik self-instruction untuk meningkatkan harga diri siswa tersebut, dapat disimpulkan bahwa penelitian ini menunjukkan hasil yang positif, terdapat peningkatan peningkatan skor harga diri pada konseli. Hasil pengukuran skor rata-rata harga diri konseli saat kondisi baseline atau sebelum penerapan teknik selfinstruction mencapai 66, yang berarti masuk pada kategori rendah. Kemudian, setelah diberikan intervensi dengan teknik self-instruction, konseli mendapatkan hasil skor rata-rata sebesar 93 termasuk pada kategori sedang. 


\section{DAFTAR PUSTAKA}

Azam, U. (2016). Bimbingan dan Konseling Perkembangan di Sekolah Teori dan Praktik. Deepublish.

Beck, J. S. (2011). Cognitive Behavior Therapy: Basics and Beyond (2nd ed.). The Guilford Press.

Branden, N. (2013). What Self-Esteem Is and Is Not.

Www.Nathanielbranden.Com. http://www.nathanielbranden.com/ what-self-esteem-is-and-is-not

Collins-Donnelly, K. (2014). Banish Your Body Image Thief A Cognitive Behavioural Therapy Workbook on Building Positive Body Image for Young People. Jessica Kingsley.

Coloroso, B. (2007). Stop Bullying: Memutus Rantai Kekerasan Anak dari Prasekolah Hingga SMU. Serambi Ilmu Semesta.

Coopersmith, S. (1967). The Antecedents of Self-esteem. Freeman and Company.

Corey, G. (2009). Theory and Practice of Counseling and Psychotherapy (8th ed.). Thomson Brooks/Cole.

Cormier, S., Nurius, P. S., \& Osborn, C. J. (2009). Interviewing and change strategies for helpers: Fundamental skills and cognitive-behavioral interventions. Brooks/Cole.

Kathryn, G. (2012). Konseling Remaja: Intervensi Praktis Bagi remaja Berisiko. Pustaka Belajar.

Khoirunafik, U. (2018). Hubungan harga diri dengan penyesuaian sosial pada remaja. In eprints.ums.ac.id (Vol. 10, Issue 2). Universitas Muhammadiyah Surakarta.

Larasati, W. P. (2012). Meningkatkan Self-Esteem Melalui Metode SelfInstruction (Enhancing Self-esteem through Self-instruction Method). Universitas Indonesia.
Liow, C. J., Andriani, I., Septrina, Ayu, M., \& Sulistiyawati, Nur, F. (2009). Hubungan Tindakan Bullying Di Sekolah Dengan Self Esteem Siswa. Proceeding PESAT (Psikologi, Ekonomi, Sastra, Arsitektur, \&Sipil), 3, 3-7.

Novianto, R. D. (2018). Catatan KPAI Bidang Pendidikan: Kasus Bullying Paling Banyak.

Nasional.Sindonews.Com. https://nasional.sindonews.com/rea d/1324346/15/catatan-kpai-bidangpendidikan-kasus-bullying-palingbanyak-1532346331

Plummer, D. (2005). Helping Adolescents and Adults to Build Self-Esteem. Jessica Kingsley.

Prabowo, A. S., Chanum, D. I., \& Hidayat, D. R. (2014). Pengaruh teknik biblioterapi terhadap peningkatan harga diri siswa yang orang tuanya bercerai di SMP Negeri 232 Jakarta. Insight: Jurnal Bimbingan Dan Konseling, 3(1), 18-23.

https://doi.org/10.21009/INSIGHT. 031.003

Putu, L., \& Lestari, S. (2014). Pelatihan Metode Self Instruction untuk Meningkatkan Self Esteem Siswa SMA. Pendidikan Dan Pengajaran, 1(47), 49-57.

Rostiana, D., Wibowo, M. E., \& Purwanto, E. (2018). The Implementation of Self Instruction and Thought Stopping Group Counseling Techniques to Improve Victim Bullying Self Esteem. Jurnal Bimbingan Konseling, 7(1), 36-40.

Sancahya, A. A. G. A., \& Susilawati, L. K. P. A. (2014). Hubungan antara dukungan sosial keluarga dengan self-esteem pada remaja akhir di kota Denpasar. Jurnal Psikologi 
Udayana, 1(3), 52-62.

Saniya. (2019). Dampak Perilaku Bullying Terhadap Harga Diri ( Self Esteem ) Remaja Di Pekanbaru. Jurnal Keperawatan, 3(73), 1-16.

Santrock, J. W. (2007). Remaja (T. B. Widyasinta (ed.); 11th ed.). Erlangga.

Simanjuntak, L. E., \& Indrawati, E. S. (2019). Hubungan antara Dukungan Sosial Teman Sebaya dengan Harga Diri pada Sisiwi Kelas XII SMA Kristen Terang Bangsa Semarang [Universitas Diponogoro].

http://eprints.undip.ac.id/74242/

Sugiono. (2013). Metode Penelitian Pendidikan. Alfabeta.

Tirsae, O. V. (2016). Pengaruh Harga Diri Terhadap Kecemasan Sosial Pada Remaja Korban Bullying Di Palangkaraya, [Universitas Sanata Dharma].

https://doi.org/10.1152/ajpcell.004 08.2012

Whiston, S. C. (2009). Principles and Applications of Assessment in Counseling (2nd ed., Vol. 39, Issue $3)$.

Brooks/Cole. https://doi.org/10.1080/07481756.2 006.11909797

WHO. (2018). Orientation programme on adolescent health for health care providers. Departement of Child and Adolescent Health and Development (CAH) World Health Organization.

Wiyani, Ardy, N. (2017). Save Our Children From School Bullying. Ar-Ruzz Media. 


\section{Lampiran}

Prosedur Pelaksanaan Penerapan Teknik Self-Instructional dalam Pendekatan Cognitive Behavior Therapy

\begin{tabular}{|c|c|c|c|c|}
\hline No & $\begin{array}{c}\text { Tahapan } \\
\text { Konseling }\end{array}$ & Langkah Treatment & Kegiatan & Durasi \\
\hline 1 & $\begin{array}{c}\text { Fase } \\
\text { baseline }\end{array}$ & Asesmen & $\begin{array}{ll}\text { 1. } & \text { Memberikan } \\
\text { pemahaman pada } \\
\text { konseli tentang } \\
\text { proses pelaksanaan } \\
\text { konseling individu } \\
\text { 2. Wawancara Awal } \\
\text { 3. } \\
\text { Mengisi Form } \\
\text { biodata konseli }\end{array}$ & $\begin{array}{c}1 \text { kali } \\
\text { pertemuan }\end{array}$ \\
\hline 2 & Fase awal & $\begin{array}{l}\text { Asesmen: } \\
\text { Konseptualisasi masalah } \\
\text { konseli }\end{array}$ & 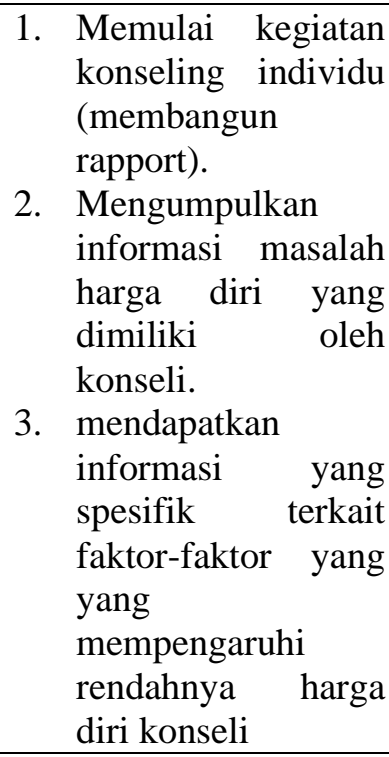 & $\begin{array}{c}2 \text { kali } \\
\text { pertemuan }\end{array}$ \\
\hline 3 & Fase awal & $\begin{array}{l}\text { Asesmen } \\
\text { Observasi diri: di awal } \\
\text { intervensi, konseli } \\
\text { diminta untuk } \\
\text { mendengarkan dialog } \\
\text { internal dalam dirinya } \\
\text { dan mengenali } \\
\text { karakteristik pernyataan } \\
\text { negatif yang ada. Proses } \\
\text { ini melibatkan kegiatan } \\
\text { meningkatkan } \\
\text { sensitivitas terhadap } \\
\text { pikiran, perasaan, } \\
\text { perbuatan, reaksi } \\
\text { fisiologis dan pola reaksi } \\
\text { terhadap orang lain. }\end{array}$ & 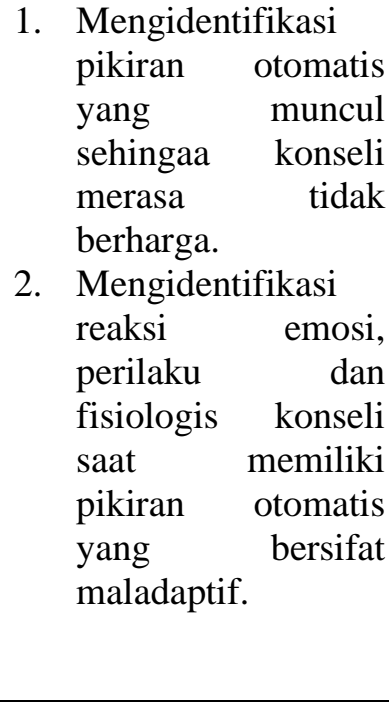 & $\begin{array}{l}1 \text { kali } \\
\text { pertemuan }\end{array}$ \\
\hline
\end{tabular}




\begin{tabular}{|c|c|c|c|c|}
\hline No & $\begin{array}{c}\text { Tahapan } \\
\text { Konseling }\end{array}$ & Langkah Treatment & Kegiatan & Durasi \\
\hline 4 & $\begin{array}{l}\text { Fase Inti / } \\
\text { fase } \\
\text { intervensi }\end{array}$ & $\begin{array}{l}\text { Memulai dialog internal } \\
\text { baru: setelah konseli } \\
\text { belajar untuk mengenali } \\
\text { tingkah laku } \\
\text { maladaptifnya, mereka } \\
\text { mulai mencari } \\
\text { kesempatan untuk } \\
\text { mengembangkan } \\
\text { alternatif tingkah laku } \\
\text { adaptif dengan cara } \\
\text { merubah dialog internal } \\
\text { dalam diri mereka. } \\
\text { Dialog internal yang } \\
\text { baru diharapkan dapat } \\
\text { menghasilkan tingkah } \\
\text { laku baru, yang } \\
\text { sebaliknya akan } \\
\text { memberikan dampak } \\
\text { terhadap struktur kognisi } \\
\text { konseli }\end{array}$ & 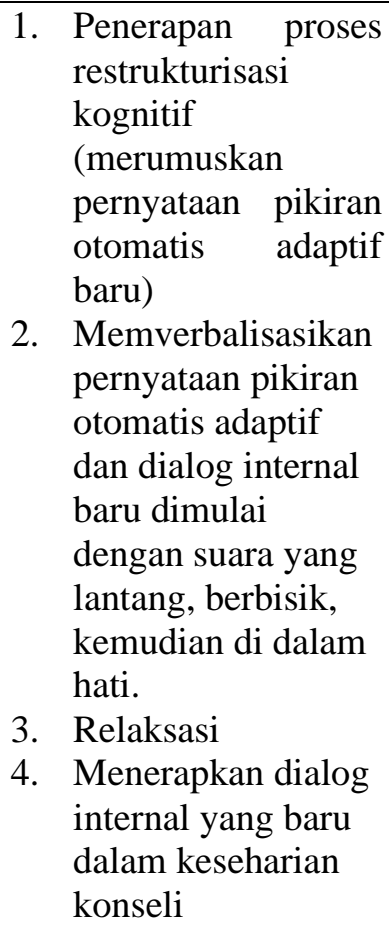 & $\begin{array}{c}4 \text { kali } \\
\text { pertemuan }\end{array}$ \\
\hline 8 & $\begin{array}{c}\text { Fase } \\
\text { inti/fase } \\
\text { intervensi }\end{array}$ & $\begin{array}{l}\text { Belajar keterampilan } \\
\text { baru: konseli kemudian } \\
\text { belajar teknik mengatasi } \\
\text { masalah yang secara } \\
\text { praktis dapat diterapkan } \\
\text { dalam kehidupan sehari- } \\
\text { hari. Pada saat yang } \\
\text { sama, konseli } \\
\text { diharapkan untuk tetap } \\
\text { memusatkan perhatian } \\
\text { kepada tugas membuat } \\
\text { pernyataan baru dan } \\
\text { mengamati perbedaan } \\
\text { hasilnya }\end{array}$ & $\begin{array}{l}\text { 1. Mrumuskan } \\
\text { perubahan perilaku } \\
\text { dan coping adaptif } \\
\text { dengan menerapkan } \\
\text { dialog internal baru } \\
\text { yang telah } \\
\text { diinstruksikan }\end{array}$ & $\begin{array}{c}1 \text { kali } \\
\text { pertemuan }\end{array}$ \\
\hline 9 & Fase akhir & $\begin{array}{l}\text { Evaluasi dan tindak } \\
\text { lanjut }\end{array}$ & $\begin{array}{ll}\text { 1. } & \text { Mengevaluasi } \\
\text { perubahan prilaku } \\
\text { dan coping adaptif } \\
\text { yang sebelumnya } \\
\text { telah dirumuskan } \\
\text { 2. } \\
\text { Merumuskan tindak } \\
\text { lanjut } \\
\text { 3. }\end{array}$ & $\begin{array}{c}1 \text { kali } \\
\text { pertemuan }\end{array}$ \\
\hline
\end{tabular}

